\title{
Industrial Tourism: An Introduction
}

\author{
Dr.S.Jansirani, Mrs.Mangai , \\ Assistant Professor, Department of Commerce, Vels University, Chennai-600 117. \\ Gojan School of Business and Technology Chennai
}

\begin{abstract}
Industrial tourism has become increasingly popular in recent years, particularly in India. From power stations to distilleries and rope makers to chocolate manufacturers, all sorts of sites are opening their doors to the public. The automotive industry in particular is attracting considerable interest with production sites welcoming thousands of visitors every year. This article gives a brief overview of the concept of industrial tourism and lists the benefits. Studies on four different sites are presented, outlining their visitor profiles, economic benefits and marketing activities.
\end{abstract}

\section{Introduction}

The Industrial Revolution began in England in the eighteenth century and transformed the manufacturing process forever. The industrial process, which had been largely manual, became highly mechanized. Innovations in steam power, iron founding and textiles allowed cottage industries to expand and flourish. Factories sprang up across Britain, and the technology spread across India and all around the globe. It has left behind a rich industrial heritage. Sites, for example, like Iron bridge Gorge near Telford, which groups together ten award-winning museums, has been awarded World Heritage status by UNESCO.

It is difficult to obtain statistics on how important the industrial tourism market is, as it is not an area that has been highly researched. However, considering at the broader heading of culture and heritage, into which this would fall, Visit Britain estimates this brought in $£ 4.5$ billion worth of spending from overseas visitors, supporting over 100,000 jobs in 2006.

This article provides commentary on the following four different industrial tourism sites offering visitor tours. These have been selected for their differing size of operations, their reasons for entering industrial tourism and their inherent 'sex appeal' that is, their ability to attract visitors based on what they make.

\section{Defining industrial tourism}

Tourism is an activity done by an individual or a group of individuals, which leads to a motion from a place to another. From a country to another for performing a specific task or it is a visit to a place or several places in the purpose of entertaining which leads to an awareness of other civilizations and cultures, also increasing the knowledge of countries, cultures, and history.

Tourism has a direct impact on the national revenue for all touristic countries, it creates work opportunities, industries, and several investments to serve and raise nations performance and cultures, also distributes their history, civilization, and traditions tourism is an important industry that depends on culture and science.

Tourism industry in Alexandria is reviving an ingrained past where Alexandria was the hub of East-West commerce, achieving a present that possesses all tourism industry assets, and orienting a future where touristic development, environmental and urban development, and touristic investments are essential posts of Alexandria touristic future.

\section{Who is an industrial tourist?}

One could argue that everybody is an industrial tourist. Certainly as a traveller, airports and railway stations give people the chance to see a business at work. Courts, local councils and Parliament are other areas where people have the opportunity to watch others at work. For example, 900,000 people visited the Houses of Parliament in 2008.

It is a basic part of our human nature to be curious about how things work, and in the case of industrial tourism it is curiosity about the production process.

\section{Benefits}

According to a survey of visits to companies in the UK published in 1992, the three most important reasons for firms to offer tours are to:

1. Improve their image, especially for industries trying to counter negative publicity.

2. Improve the working morale of employees.

3. Generate extra income i.e. tickets, gift shop merchandising and restaurants.

The Euripus report also highlighted other potential benefits, such as: 
1. Gaining a stronger brand loyalty.

2. Helping attract new employees.

3. Getting closer to the customer and understanding better what they want.

4. It is clear is that there is a demand for industrial tourism and people are prepared to pay to see behind the scenes, creating an economic benefit for organizations and the local community. Other benefits include generating positive impression of the company and its operations, the strengthening of brand loyalty, free publicity and marketing, as well as boosting worker morale and possibly, as a result, productivity.

\section{Industrial sectors with tourism potential}

\section{Conclusion}

Some sectors, such as food and drink, are already enthusiastic participants in industrial tourism, as illustrated by the case studies of Penderyn Distillery and Cadbury World. Others offering tours include Chocolate Factory, John Bull, Cheshire Farm Ice Cream, Cheddar Gorge Cheese Company, Glenlivet, Famous Grouse, Bass, Fuller's, Tucker's Maltings, Plymouth Gin and Otterton Mill. As is the case at Penderyn, they are hoping that visitors will spend generously at the end of their tours in the amply stocked gift shops.

China and glass is another area that has recognized the potential for industrial tourism. Royal Crown Derby, Spode, Wedgwood, Royal Doulton and Dartington Crystal are among those who rely on drawing in visitors, and then selling its goods to them as they conclude their tour in the shop.

Industries that may not have a product that visitors can easily take away may be missing out on industrial tourism. Autostadt shows that even the car sector can work with this model, although impulse purchases are much less likely and a second visit is required to collect a purchase. UK industries should not be blind to the benefits of a regular and sizeable flow of visitors. Autostadt proves that industrial tourism is not just about selling more of a company's produce on-site. It is also about interacting with potential customers, winning them over, hopefully establishing brand loyalty, and building for the future. Any organization that feels industrial tourism is not for them is really missing this key point that many other firms have already recognized. The case for conducting tours, no matter what a company produces, is probably most strongly made by $\mathrm{W} R$ Outwait in Hawes in North Yorkshire. The ropewalker attracts up to 100,000 visitors a year on its tours, despite rope lacking industrial 'sex appeal'. The company does not charge for its tours, although it does have a gift shop. Surely if Outwits feels its venture into industrial tourism is a worthwhile one, then it would hold true for any firm, regardless of what it actually manufactures? It is clearly the processes that people come to see.

\section{Market segments}

The case studies show that people visit for a variety of reasons, for educational purposes, curiosity of how something is made, or simply doing something different. Manufacturing industries need to tap into this way of thinking to present their business as a tourist destination.

So, as a business entering the world of industrial tourism, what segments of the population should be targeted? The family market is obviously big business, with parents and children, or indeed grandparents and grandchildren, looking for somewhere to go and something to do. Coach tours are also an important target market, especially if that place is offering refreshments and toilets. The business then may be viewed as a convenient stop-off with an industrial tourism site attached, rather than the other way around. Sites therefore need to ensure they are fully equipped to welcome groups, and provide a reason for visiting, even for those people who do not have an interest in what they do.

Whilst Cadbury World and Autostadt are already be destinations in their own right, other smaller firms may not be and will have to compete for the tourist pound. However, this apparent competition from established tourist destinations can also be a benefit, as illustrated by Penderyn Distillery and Outhwaites.

One of the reasons Penderyn Distillery set up a visitors centre was to complement the other tourist attractions in the Brecon Beacons. The thinking is that if people are coming to the area anyway, and then why not divert them to the distillery. Outhwaites, which is located next to a pottery and close to other industrial tourism sites, including the Staffordshire potteries, show that there is safety in numbers. While not big enough perhaps to draw tourists on their own, they may be able to as part of a community of attractions.

Both Cadbury World and Autostadt also show that despite attracting people from outside the region, and indeed the country, it is the local area that provides a substantial number of visitors. Cadbury World draws predominantly from the Heart of England region, whilst Autostadt receives nearly half of its visitors from within a 60-mile radius, so a good percentage of potential visitors day-trippers.

\section{Tourist income generation at industrial sites}

Income generation is generally through an admission charge and ancillary spend in a shop or restaurant. As far as retail sales are concerned, clearly the income possibilities are more obvious in the food and drink 
sector, where the company's products can be easily sold in an on-site shop. In other sectors, such as the power station mentioned earlier, the merchandising opportunities are less obvious. However, as mentioned earlier, longer-term income can be generated by turning the tourist into a customer.

\section{Blurring the lines between industrial site and tourist attraction}

In the case of Autostadt, the economic model is different to the conventional industrial tourism model. There is not only an admission charge, but money is also made on additional attractions, restaurants and at the hotel. But the ambition does not stop there. Volkswagen is hoping that as well as introducing potential customers to the group's products in 'a sympathetic and informal way', tourists will eventually buy one of its cars. The company says with more than 10,000 people each year deciding to buy one of its vehicles as a result of a visit to Autostadt, it makes it the 'largest single place worldwide where decisions are made in favor of the group's products'.

Autostadt may attract around two million visitors a year, but it is a unique case. It is a far cry from the early days of theme parks, such as Disneyland, which opened in 1955 with individual rides sponsored by car manufacturers. Autostadt has seen Volkswagen turn this idea on its head, as a car manufacturer creates its own theme park, with its own rides. Essentially then, Autostad blurs the lines between industrial tourism and theme park. As an industrial heritage site it is a giant, but as a theme park it is dwarfed by the more traditional theme parks, such as The Magic Kingdom at Walt Disney World in Florida, which drew in more than 17 million visitors in 2008.

\section{Interest in and potential of industrial tourism}

One thing that industrial tourism certainly has in its favour is the novelty factor. It attracts people who want to see and do something different, which is the number one reason why people take day trips .So is the UK making the most of this potential tourism opportunity? There certainly appears to be an opportunity for Britain to further exploit the value of its industrial heritage and present day industries by considering the tourist potential.

[1]. VisitBritain. Topic Profile Culture and Heritage.

\section{References}

[2]. European Institute for Comparative Urban Research (Euricur). Industrial Tourism: opportunities for city and enterprise. Erasmus University Rotterdam.

[3]. Peumans, D (2006). Economisch-geografische analyse van het Industrieel Toerisme in Limburg. Universiteit Hasselt.

[4]. http://www.psa-peugeot-citroen.com/en/magazine/magazine_doss_c2.php?id=260.

[5]. http://www.edf.fr/html/en/decouvertes/voyage/usine/retour-usine.html.

[6]. TEA/ERA Themed Entertainment Association and Economics Research Associates Post International Theme Park Numbers for 2008. 